\title{
The TIMI trials - 25 years of clinical research (1984-2009)
}

\author{
Jindrich Spinar, Jiri Vitovec*, Lenka Spinarova* \\ Department of Internal Medicine, Brno University Hospital and Masaryk University School of Medicine, *Department of \\ Internal Medicine/Cardiology/Angiology, St Ann University Hospital and Masaryk University School of Medicine, Brno, \\ Czech Republic
}

Spinar J, Vítovec J*, Spinarova L* (Department of Internal Medicine, Brno University Hospital and Masaryk University School of Medicine, *Department of Internal Medicine/Cardiology/Angiology, St Ann University Hospital and Masaryk University School of Medicine, Brno, Czech Republic). The TIMI trials - 25 years of clinical research (1984-2009). Cor Vasa 2008;50(12):480-485.

The TIMI group has celebrated 25 years of its existence and 50 clinical trials conducted during the American Heart Association (AHA) Annual Meeting held in New Orleans in November 2008. The TIMI group was founded in 1984, with Professor Eugene Braunwald being the leading cardiologist of the group since the very beginning. TIMI has evolved into a wide array of phase I to phase IV trials as well as registries. These have ranged in size from less than 30 to more than 300,000 subjects.

The TIMI group has formulated several definitions in cardiology, e.g., the myocardial infarction definition, TIMI bleeding definition, TIMI flow grade (perfusion grade) definition, TIMI thrombus grade definition, TIMI risk scores, and others. Results of the trials conducted by TIMI group have changed the daily practice of cardiology all over the world. The Czech Republic is proud to be part of the TIMI group and TIMI trials.

Key words: TIMI - Clinical trials - Myocardial infarction - Bleeding - Blood flow - Risk score

Špinar J, Vítovec J*, Špinarová L* (Interní klinika, Fakultní nemocnice Brno a Lékařská fakulta Masarykovy univerzity, *I. interní kardioangiologická klinika, Fakultní nemocnice u sv. Anny a Lékařská fakulta Masarykovy univerzity, Brno, Česká republika). Studie TIMI - 25 let klinického výzkumu (1984-2009). Cor Vasa 2008;50(12):480-485.

Skupina TIMI oslavila 25 let existence a 50 provedených klinických studií během výroční konference American Heart Association (AHA), která se konala v listopadu 2008 v americkém New Orleans. Skupina TIMI vznikla v roce 1984 a prof. E. Braunwald byl od samého počátku jejím hlavním odborníkem v oblasti kardiologie. Skupina TIMI se účastnila řady klinických studií fáze I až IV i registrů v rozsahu od 300 do více než 300000 pacientů.

Skupina TIMI vypracovala několik definicí v oblasti kardiologie, např́klad: definici infarktu myokardu, definici krvácení podle TIMI, definici stupně průtoku (stupně perfuze) podle TIMI, definici stupně trombu podle TIMI, riziková skóre podle TIMI a další.

Výsledky studií provedených skupinou TIMI změnily každodenní praxi kardiologů na celém světě. Odborníci z České republiky si váží možnosti být součástí skupiny TIMI a podílet se na provádění studií této skupiny.

Klíčová slova: TIMI - Klincké studie - Infarkt myokardu - Krvácení - Průtok krve - Rizikové skóre

Address: Prof Jindrich Spinar, MD, PhD, Department of Internal Medicine, Brno University Hospital, Jihlavska 20, 62500 Brno, Czech Republic e-mail: jspinar@fnbrno.cz

The first clinical trial of the TIMI group was published in 1985: The TIMI Study Group. The Thrombolysis in Myocardial Infarction (TIMI) Trial; Phase I findings. N Engl J Med 1985;312:932-936; and this was the beginning of a very successful era. The TIMI group marked 25 years of its existence and 50 clinical trials during the American Heart Association (AHA) congress in New Orleans in November 2008 (Figures 1 and 2).

Since it inception in 1984, the principal goal of the TIMI Study Group has been to conduct high-quality clinical trials that enhance the care of patients with coronary disease. TIMI has evolved into a wide array of phase I to phase 4 trials as well as registries. These have ranged in size from less than 30 to more than 300,000 subjects. The intervention studies include fibrinolytics, antithrombotic, antiplatelet, anti-ischemic and lipid-lowering agents as well as percutaneous coronary intervention. In addition, the TIMI Study Group has used its growing database of clinical findings, biomarkers and genetic tests to enhance the

This research was supported by Research Project MSM0021622402, awarded by the Ministry of Education, Youth and Sports of the Czech Republic. 


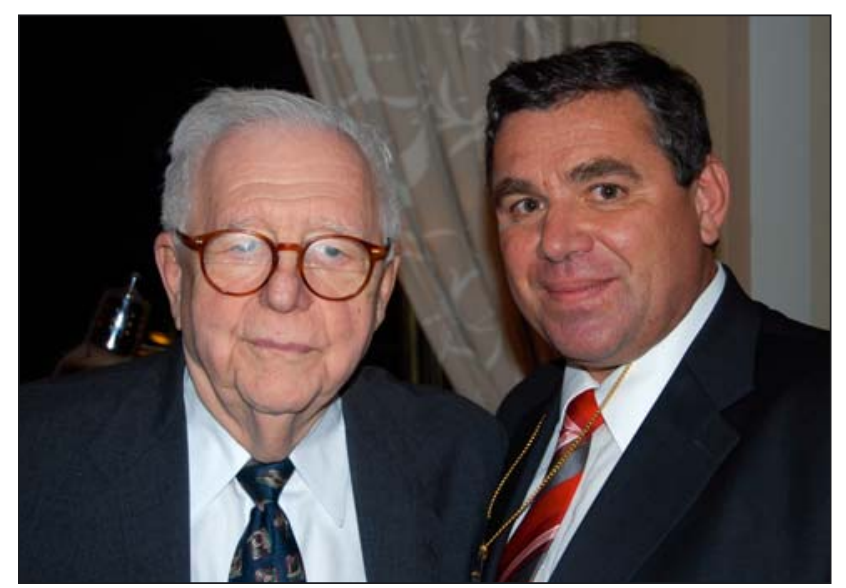

Figure 1 Prof. Braunwald and Prof. Spinar celebrating 25 years of TIMI group - New Orleans 2008

understanding of coronary artery disease. An important corollary goal has been to train the next generation of clinical investigators. TIMI is especially proud of those trainees who have assumed leadership positions in leading institutions around the world.

Since it foundation, the leader person of the TIMI group is Eugene Braunwald, M.D., preeminent researcher, physician, and educator. According to Joseph B. Martin, M.D., former Dean of the Faculty of Medicine at Harvard (Medical School), Dr Braunwald's "bench to bedside approach to the limitations of myocardial infarct size, i.e., perhaps the greatest single example of an individual whose scientific research has led to dramatic translational benefit to improve patient care". Dr Braunwald's direct contributions as a clinical investigator have improved the prognosis and quality of life for patients with cardiovascular disease. The national representatives (Czech Republic) in the TIMI group are Prof. Petr Widimsky, M.D., and Prof. Jindrich Spinar, M.D.

The TIMI group has formulated several definitions in cardiology. We present some examples:

\section{MYOCARDIAL INFARCTION}

\section{Non-ST-Elevation:}

Acute - must satisfy criteria ( 1 and 2 ) and (3 or 4 ):

(1) Absence of new or presumably new ST-elevation $\geq 0.1 \mathrm{mV}$ in 2 or more contiguous ECG leads;

(2) Clinical scenario consistent with $\mathrm{MI}$;

(3) Elevated enzymes (CK-MB > ULN or, in the absence of CK-MB, a total CK $>2 \mathrm{x}$ ULN or elevation of other accepted markers of MI such as troponin) within 24 hours of the onset of ischemic discomfort;

(4) New $\mathrm{Q}$-waves evolved on the ECG distinct from time of presentation.

\section{ST-Elevation:}

Acute - must satisfy criteria ( 1 and 2 ) and (3 or 4 ) below:

(1) Presence of new or presumably new ST-elevation $\geq 0.1 \mathrm{mV}$ in 2 or more contiguous ECG leads felt to be ischemic and without other explanation of ST-elevation, such as acute pericarditis or ventricular aneurysm,

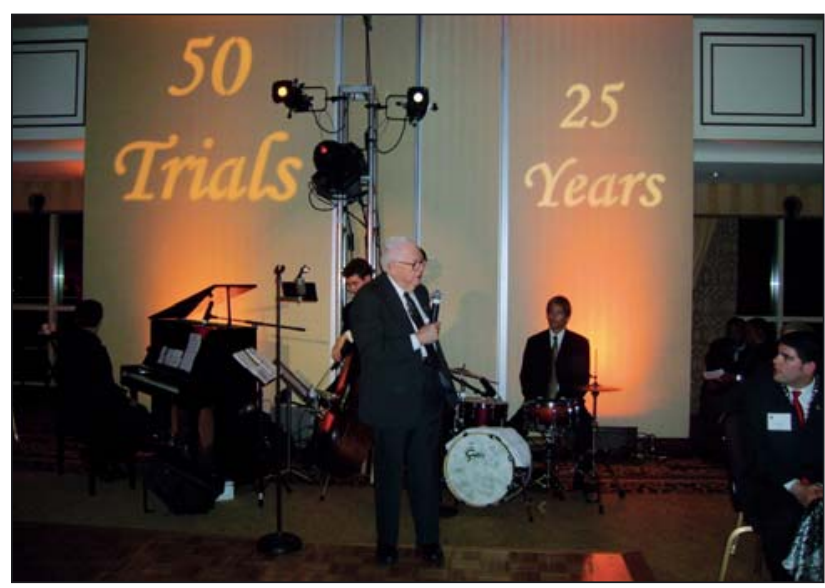

Figure 2 Prof. Braunwald opening the celebration ceremony

(2) Clinical scenario consistent with myocardial infarction;

(3) Elevated enzymes (CK-MB > ULN or, in the absence of CK-MB, a total CK $>2 x$ ULN or elevation of troponin) within 24 hours of the onset of ischemic discomfort;

(4) New $\mathrm{Q}$-waves distinct from time of presentation.

\section{TIMI BLEEDING DEFINITION}

Minimal: Any clinically overt sign of hemorrhage (including imaging) that is associated with a fall in hemoglobin $<3 \mathrm{~g} / \mathrm{dL}$ (or, when hemoglobin is not available, a fall in hematocrit of $<9 \%$ ).

Minor: Any clinically overt sign of hemorrhage (including imaging) that is associated with a fall in hemoglobin of 3 to $\leq 5 \mathrm{~g} / \mathrm{dL}$ (or, when hemoglobin is not available, a fall in hematocrit of 9 to $\leq 15 \%$ ).

Major: (1) if it is intracranial, or (2) if there are clinically significant overt signs of hemorrhage associated with a drop in hemoglobin of $>5 \mathrm{~g} / \mathrm{dL}$ (or, when hemoglobin is not available, an absolute drop in hematocrit of $>15 \%$; (3) if CABG-related: fatal bleeding or perioperative intracranial bleeding or reoperation following closure of the sternotomy incision for the purpose of controlling bleeding or transfusion of $\geq 5$ units of whole blood within a 48 hour period (cell saver transfusion will not be counted in calculations of blood products) or chest tube output $>2 \mathrm{~L}$ within a 24 -hour period.

\section{TIMI FLOW GRADE (PERFUSION GRADE) DEFINITION}

TIMI 0: complete occlusion

Dye fails to enter the microvasculature. There is either minimal or no ground glass appearance ("blush") or opacification of the myocardium in the distribution of the culprit artery indicating lack of tissue level perfusion.

TIMI 1: penetration of obstruction by contrast but no distal perfusion

Dye slowly enters but fails to exit the microvasculature. There is the ground glass appearance ("blush") or opacification of the myocardium in the distribution of the culprit lesion that fails to clear from the microvasculature, and dye staining is present on the next injection (approximately 30 seconds between injections). 
TIMI 2: perfusion of entire artery but delayed flow Delayed entry and exit of dye from the microvasculature. There is the ground glass appearance ("blush") or opacification of the myocardium in the distribution of the culprit lesion that is strongly persistent at the end of the washout phase (i. e. dye is strongly persistent after 3 cardiac cycles of the washout phase and either does not or only minimally diminishes in intensity during washout).

TIMI 3: full perfusion, normal flow

Normal entry and exit of dye from the microvasculature. There is the ground glass appearance ("blush") or opacification of the myocardium in the distribution of the culprit lesion that clears normally, and is either gone or only mildly/moderately persistent at the end of the washout phase (i. e. dye is gone or is mildly/ moderately persistent after 3 cardiac cycles of the washout phase and noticeably diminishes in intensity during the washout phase) similar to that in an uninvolved artery. Blush that is of only mild intensity throughout the washout phase but fades minimally is also classified as grade 3 .

\section{TIMI THROMBUS GRADE (ASSESSED VISUALLY)}

Grade 0: None - no cineangiographic characteristics of thrombus present;

Grade 1: Possible thrombus present - angiography demonstrates characteristics such as reduced contrast density, haziness, irregular lesion contour or a smooth convex "meniscus" at the site of total occlusion suggestive but not diagnostic of thrombus;

Grade 2: Thrombus present (small size) - definite thrombus with greatest dimensions less than or equal to $1 / 2$ vessel diameter;

Grade 3: Thrombus present (moderate size) - definite thrombus but with greatest linear dimension greater than $1 / 2$ but less than 2 vessel diameters;

Grade 4: Thrombus present (large size) - as in Grade 3 but with the largest dimension greater than or equal to 2 vessel diameters;

Grade 5: Total occlusion.

\section{TIMI RISK SCORES (Table I, Table II)}

Table I

STEMI risk score

\begin{tabular}{ll}
\hline \hline Criteria & Points \\
\hline Age $>75$ yrs & 3 \\
\hline Age 65-74 yrs & 2 \\
\hline Diabetes mellitus, hypertension or angina & 1 (total) \\
\hline SBP < 100 mmHg & 3 \\
\hline HR $>100$ bpm & 2 \\
\hline Killip Class II-IV & 2 \\
\hline Weight $<67$ kg & 1 \\
\hline Anterior ST elevation or LBBB & 1 \\
\hline Time to Treatment $>4$ hours & 1 \\
\hline TIMI Risk Score & $0-14$ \\
\hline \hline
\end{tabular}

Risk of death by 30 days $0=0.8 \%, 1=1.6 \%, 2=2.2 \%$, $3=4.4 \%, 4=7.3 \%, 5=12.4 \%, 6=16.1 \%, 7=23.4 \%$, $8=26.8 \%,>8=35.9 \%$
Table II

Unstable angina, NSTEMI risk score

\begin{tabular}{ll}
\hline \hline Criteria & Points \\
\hline Age $>65$ years & 1 \\
\hline$\geq 3$ CAD risk factors (family history, & 1 \\
$\begin{array}{l}\text { hypertension, diabetes mellitus, } \\
\text { hypercholesterolemia, active smoker) }\end{array}$ & \\
\hline Known CAD (Stenosis $\geq 50 \%$ ) & 1 \\
\hline Aspirin use within last 7 days & 1 \\
\hline $\begin{array}{l}\text { Recent severe angina } \\
\text { (22 anginal symptoms within 24 hours) }\end{array}$ & 1 \\
\hline Elevated Cardiac Markers & 1 \\
\hline ST segment deviation $\geq 0.5$ mm & 1 \\
\hline TIMI Risk Score & $0-7$ \\
\hline \hline
\end{tabular}

Risk of death, MI or urgent revascularisation by 14 days $0 / 1=4.0 \%, 2=8.3 \%, 3=13.3 \%, 4=19.9 \%, 5=26.2 \%$, $6 / 7=40.9 \%$

The 50 clinical trials conducted by the TIMI Study Group are listed in Table III.

Key lessons from the clinical trials conducted by TIMI Study Group are:

1. Tissue plasminogen activator (tPA) improves reperfusion and clinical outcomes when compared with streptokinase (SK) in patients receiving thrombolytic therapy in STEMI. The TIMI Flow Grade is universally used to asses pericardial perfusion at angiography. A higher TIMI Flow Grade is strongly associated with increased survival (TIMI 1).

2. The TIMI Bleeding Classification is widely used across clinical trials to grade severity of bleeding. Bleeding has been shown to be associated with an increased risk of adverse outcomes (TIMI 2).

3. Early administration of intravenous beta-blocker reduces the risk of reinfarction or recurrent ischemia in stable patients with STEMI (TIMI 2B).

4. The TIMI Risk Score for UA/NSTEMI is a simple prognostication scheme that categorizes a patient's risk of death and ischemic events and provides a basis for therapeutic decision making (TIMI 11B).

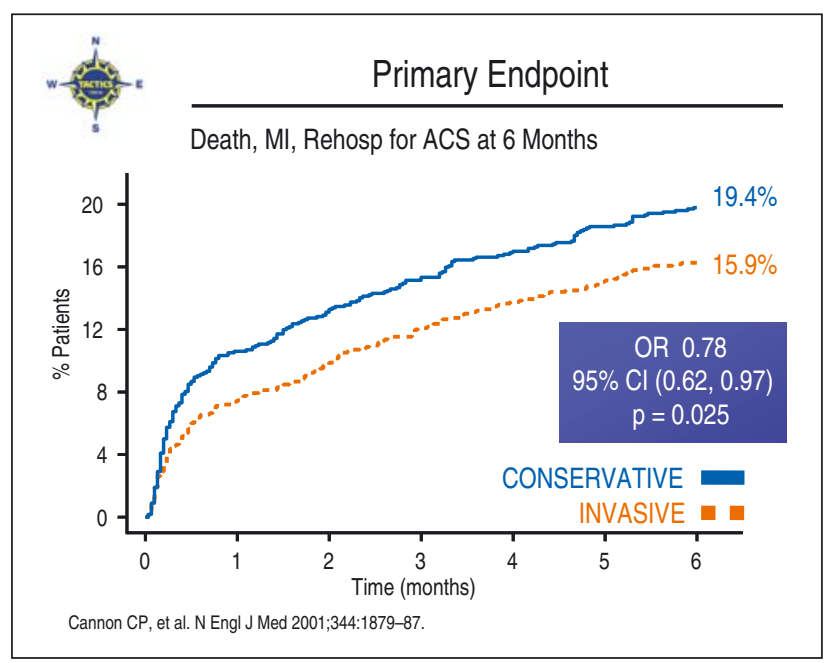

Figure 3 Primary endpoint in the TIMI 18 trial 
Table III

Clinical trials conducted by the TIMI Study Group

\begin{tabular}{|c|c|c|}
\hline Trial Name & Indication & Comparison \\
\hline TIMI 1 & STEMI & tPA vs. SK \\
\hline TIMI $2 \mathrm{~A}$ & STEMI & Immediate vs. delayed angioplasty \\
\hline TIMI 2B & STEMI & Invasive vs. conservative strategy/immediate vs. delayed metoprolol \\
\hline TIMI 3A & UA/NSTEMI & Thrombolysis vs. placebo \\
\hline TIMI 3B & UA/NSTEMI & Thrombolysis vs. placebo/invasive vs. conservative strategy \\
\hline TIMI 3 Registry & UA/NSTEMI & Natural history study \\
\hline TIMI 4 & STEMI & tPA vs. APSAC vs. combination \\
\hline TIMI 5 & STEMI & Hirudin vs. heparin in conjunction with tPA \\
\hline TIMI 6 & STEMI & Hirudin vs. heparin in conjunction with SK \\
\hline TIMI 7 & UA & Hirulog dose-ranging \\
\hline TIMI 8 & UA/NSTEMI & Hirulog vs. heparin \\
\hline TIMI 9A/B & STEMI & Hirudin vs. heparin in conjunction with thrombolytic \\
\hline TIMI 9 Registry & STEMI & Natural history study \\
\hline TIMI 10A & STEMI & TNK dose-ranging \\
\hline TIMI $10 \mathrm{~B}$ & STEMI & TNK vs tPA (angiographic) \\
\hline ASSENT 1-(TIMI 10C) & STEMI & TNK dose-ranging \\
\hline TIMI $11 \mathrm{~A}$ & UA/NSTEMI & Enoxaparin dose-ranging \\
\hline TIMI $11 \mathrm{~B}$ & UA/NSTEMI & Enoxaparin vs. heparin \\
\hline TIMI 12 & Post-ACS & Oral GP IIb/IIIa inhibitor dose-ranging \\
\hline TIMI 14 & STEMI & Abciximab \pm low dose tPA/SK \\
\hline TIMI $15 \mathrm{~A}$ & ACS & IV GP IIb/IIIa inhibitor dose-ranging \\
\hline TIMI 15B & ACS & IV + oral GP IIb/IIIa inhibitor - dose-ranging \\
\hline OPUS-TIMI 16 & ACS & Oral GP IIb/IIIa inhibitor vs. placebo \\
\hline InTIME 2-TIMI 17 & STEMI & nPA vs. tPA \\
\hline TACTICS-TIMI 18 & UA/NSTEMI & Invasive vs. conservative therapy with tirofiban \\
\hline ER-TIMI 19 & STEMI & Early rPA vs. standard therapy \\
\hline 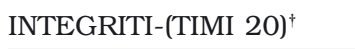 & STEMI & Eptifibatide \pm TNK-tPA (angiographic) \\
\hline A2Z-(TIMI 21$)^{+}$ & ACS & Tirofiban + (enoxaparin vs. heparin)/simvastatin early vs. late \\
\hline PROVE IT-TIMI 22 & Post-ACS & $\begin{array}{l}\text { Pravastatin vs. atorvastatin/ } \\
\text { gatifloxacin vs. placebo }\end{array}$ \\
\hline ENTIRE-TIMI 23 & STEMI & Abciximab \pm TNK/enoxaparin vs. heparin (angiographic) \\
\hline 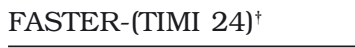 & STEMI & Tirofiban \pm TNK (angiographic) \\
\hline EXTRACT-TIMI 25 & STEMI & Enoxaparin vs. heparin in conjunction with thrombolytic \\
\hline JUMBO-TIMI 26 & PCI & Prasugrel vs. clopidogrel \\
\hline PROXIMATE-TIMI 27 & Stable CAD & Monoclonal antibody ( $\mathrm{CH}-36 \mathrm{Mab})$ against tissue factor dose-ranging \\
\hline CLARITY-TIMI 28 & STEMI & Clopidogrel vs. placebo with thrombolytic \\
\hline ADVANCE MI-(TIMI 29) ${ }^{\dagger}$ & STEMI & $\begin{array}{l}\text { Facilitated PCI (eptifibatide }+ \text { TNK) vs. direct PCI (eptifibatide }+ \\
\text { placebo)/enoxaparin vs. heparin }\end{array}$ \\
\hline PROTECT-TIMI 30 & PCI & Bivalirudin vs. heparin + eptifibatide \\
\hline TIMI 31 & STEMI & Fibrinolytic (BB - 10153) dose-ranging \\
\hline ANTHEM-TIMI 32 & UA/NSTEMI & Tissue factor/fVIIa inhibitor (rNAPc2) vs. placebo \\
\hline DISPERSE2-TIMI 33 & US/NSTEMI & AZD6140 vs. clopidogrel \\
\hline TITAN-TIMI 34 & STEMI & ED vs. catheterization lab initiated eptifibatide with primary PCI \\
\hline PROMPT-TIMI 35 & Stable CAD & Novel markers of ischemia during ETT \\
\hline MERLIN-TIMI 36 & UA/NSTEMI & Ranolazine vs. placebo \\
\hline TIMI-37A & STEMI & PARP inhibitor in STEMI \\
\hline
\end{tabular}


Continue the table

\begin{tabular}{lll}
\hline \hline Trial Name & Indication & Comparison \\
\hline TRITON-TIMI 38 & PCI in ACS & Prasugrel vs. clopidogrel in PCI \\
\hline Early ACS-(TIMI 39) & UA/NSTEMI & Early eptifibitide vs. placebo before PCI \\
\hline IMPROVE IT-(TIMI 40)** & Post-ACS & Simvastatin vs. Vytorin (ezetimibe + simvastatin) \\
\hline PLATO-(TIMI 41) & ACS & AZD6140 vs. clopidogrel \\
\hline SEPIA-TIMI 42* & NSTEMI & Otamixaban vs. heparin with PCI \\
\hline AVANT GARDE-TIMI 43* & Post-ACS & Aliskiren vs. valsartan vs. placebo to reduce NT-proBNP \\
\hline PRINCIPLE -TIMI 44* & PCI & Prasugrel vs. clopidogrel to inhibit platelet aggregation \\
\hline VERIFY NOW-TIMI 45* & CABG & Platelet inhibition and bleeding in CABG patients \\
\hline ATLAS-TIMI 46* & Post-ACS & Rivaroxaban vs. placebo \\
\hline IC TITAN-TIMI 47* & PCI & IC eptifibatide vs. placebo \\
\hline ENGAGE-TIMI 48* & Atrial fibrillation & Oral Xa inhibitor (DU-176b) vs. warfarin in atrial fibrillation \\
\hline ICE-T-TIMI 49* & STEMI & Intracoronary fibrinolytic vs. placebo \\
\hline TRA 2P-TIMI 50* & $\begin{array}{l}\text { Stable athero- } \\
\text { sclerotic disease }\end{array}$ & Trombin receptor antagonist (SCH 530348 vs. placebo \\
\hline \hline
\end{tabular}

*Ongoing

†In conjunction with Duke Clinical Research Institute

ACS - Acute coronary syndrome, CAD - Coronary artery disease, ETT - exercise tolerance test, LMWH - low molecular weight heparin, NSTEMI - non-ST-elevation myocardial infarction, PCI - percutaneous coronary intervention, STEMI - ST-elevation myocardial infarction, UA - unstable angina

The Czech Republic is participating in the following ongoing trials: IMPROVE IT (TIMI 40), PLATO (TIMI 41), SEPIA (TIMI 42), AVANT GARDE (TIMI 43), ATLAS (TIMI 46), ENGAGE (TIMI 48), TRA 2P (TIMI 50).

5. Treatment with on oral glycoprotein IIb/IIIa increased the risk of death and did not appear to offer any net clinical benefit in patients with ACS (TIMI 16).

6. The TIMI Risk Score for STEMI is a useful tool for helping to identify those individuals at increased risk of death after STEMI (TIMI 17).

7. An early invasive strategy reduces death, recurrent MI or rehospitalization for ACS in patients with NSTE-ACS, as compared with a conservative treatment strategy. Troponin is a powerful predictor of outcomes and is useful for helping to identify individuals who may benefit more from particular treatment strategies including GP

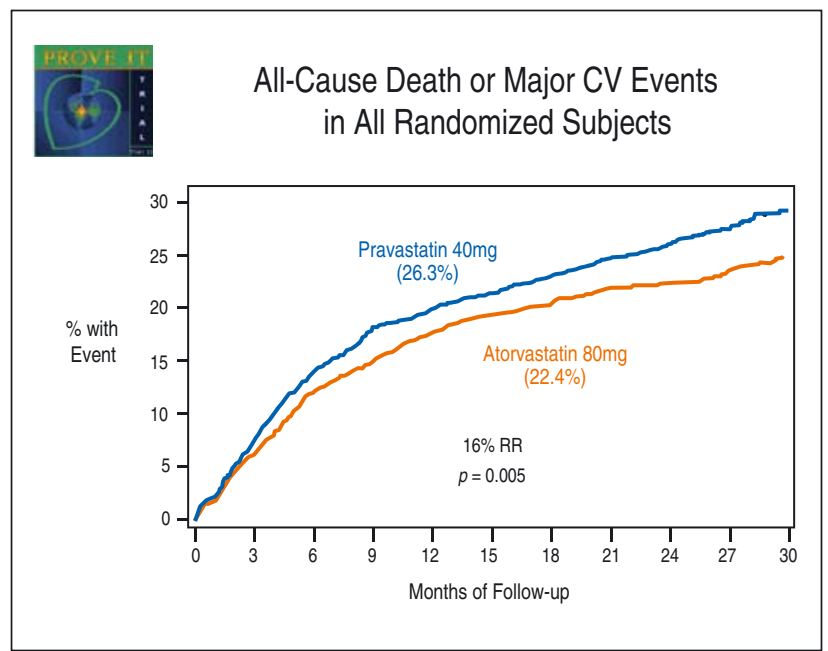

Figure 4 Primary endpoint in the TIMI 22 trial
IIb/IIIa inhibitors and an early invasive strategy in NSTEMI (TIMI 18) (Figure 3).

8. B-type natriuretic peptide (BNP) is a powerful predictor of risk of death after ACS (TIMI 21).

9. After ACS, intensive lipid-lowering therapy with high-potency statin significantly reduces the risk of adverse outcomes as compared to moderate-potency statin therapy. When measured 30 days after ACS, high-sensitivity C-reactive protein (hsCRP) is a powerful predictor of outcomes, independent of achieved LDL concentration. Intensive statin therapy significantly reduces hsCRP and, in part, helps to attenuate the increased risk of death or MI seen with higher levels of hsCRP (TIMI 22) (Figure 4).

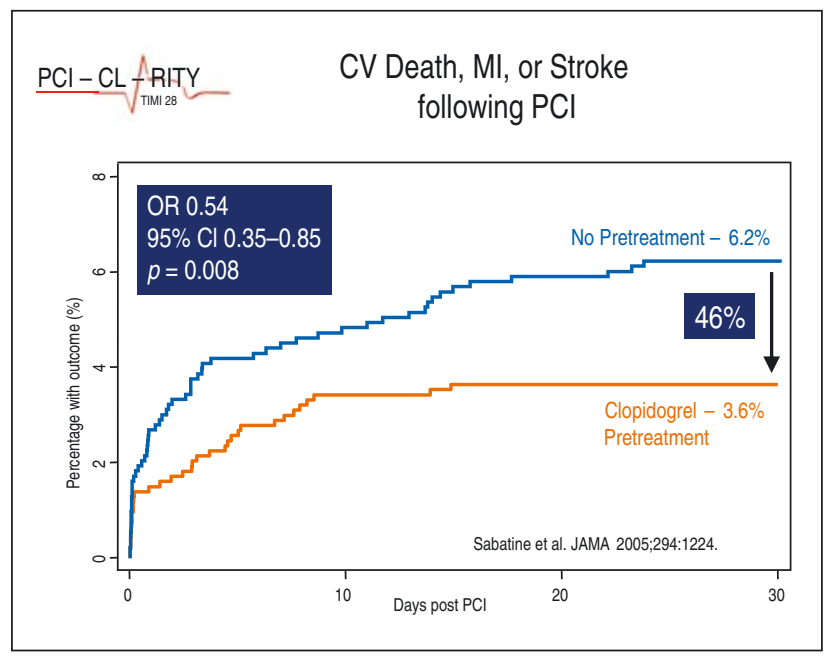

Figure 5 Primary endpoint in the TIMI 28 trial 


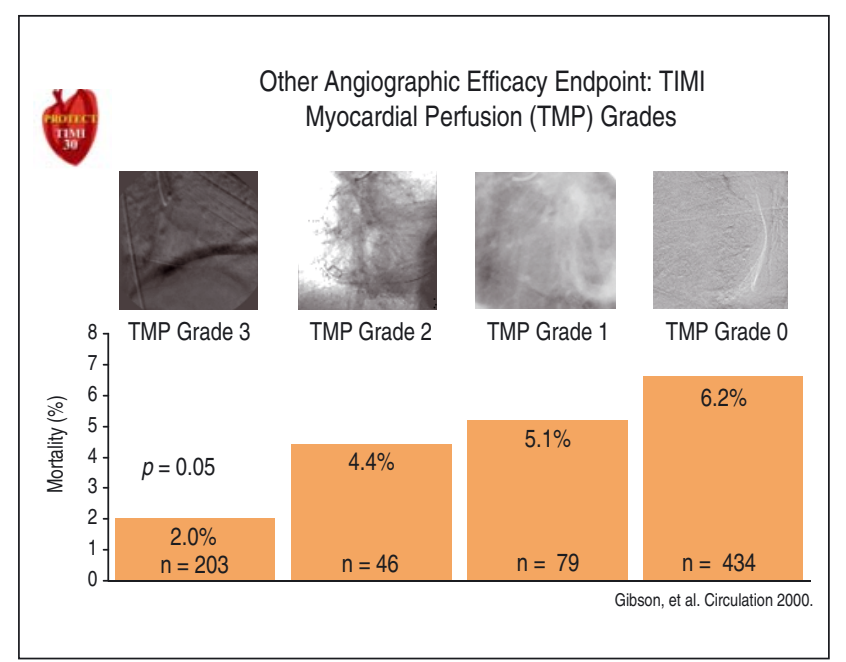

Figure 6 TIMI Myocardial perfusion grades and mortality in the TIMI 30 trial

10. Clopidogrel is a pro-drug that requires several hours to form its active metabolite. Patients treated with clopidogrel hours or days to PCI have a lower risk of events after PCI compared with those given clopidogrel at the time of catheterization. Clopidogrel improves both the angiographic and clinical outcomes in patients receiving thrombolytic therapy in STEMI (TIMI 28) (Figure 5).

11. TIMI Myocardial Perfusion grades predict mortality after PCI (TIMI 30) (Figure 6).

12. A strategy of early initiation of eptetibafide in the emergency department before primary PCI in STEMI improves angiographic outcomes without a significant increase in bleeding (TIMI 34).

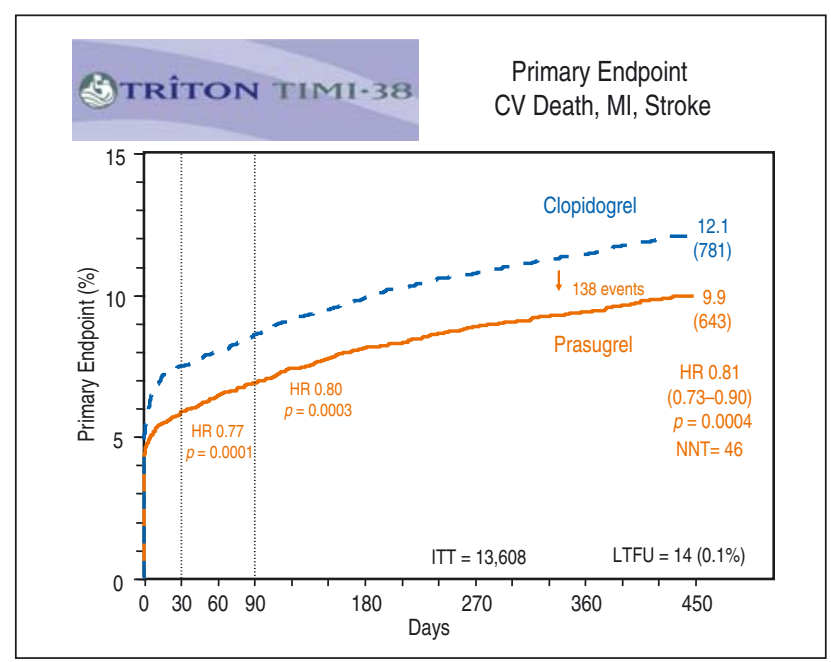

Figure 7 Primary endpoint in the TIMI 38 trial

13. Ranolazine reduces recurrent ischemia after NSTE-ACS, but does not significantly change the risk of death or recurrent MI (TIMI 36).

14. More potent platelet inhibition with prasugrel significantly improves outcomes in patients with ACS undergoing PCI as compared with clopidogrel but with an increased risk of bleeding (TIMI 38) (Figure 7).

15. In patients undergoing elective $\mathrm{PCI}$, prasugrel leads to greater inhibition than a $600 \mathrm{mg}$ loading dose or $150 \mathrm{mg}$ maintenance dose of clopidogrel. The antiplatelet effect of prasugrel can be seen as early as 15 minutes after ingestion (TIMI 44).

Received 18 November 2008

Accepted 25 November 2008 